\section{KULTURA i SPOLECZEX'ISTWO \\ POLSKA AKADEMIA NAUK \\ KOMITET SOCJOLOGII \\ INSTYTUT STUDIÓW POLITYCZNYCH \\ 2016, nr 4}

ELŻBIETY TARKOWSKIEJ SOCJOLOGIA OTWARTA

ELŻBIETA TARKOWSKA $i$ JACEK TARKOWSKI

\title{
„AMORALNY FAMILIZM”, CZYLI O DEZINTEGRACJI SPOŁECZNEJ W POLSCE LAT OSIEMDZIESIĄTYCH
}

\section{UWAGI WPROWADZAJĄCE}

Przedmiotem naszych rozważań są pewne zjawiska z dziedziny stosunków międzyludzkich, charakterystyczne dla społeczeństwa polskiego drugiej połowy lat osiemdziesiątych, związane ze szczególną rolą małych grup i nieformalnych powiązań w życiu społecznym Polaków. Interesujące nas zjawiska nie są nowe - nie pojawiły się dopiero $\mathrm{w}$ latach osiemdziesiątych. Przeciwnie, są one trwałe, niejako immanentne dla powojennej rzeczywistości polskiej. Ich względnie lepsza w ostatnich latach „widoczność” spowodowana jest tym, iż kryzys lat osiemdziesiątych uwydatnił wiele zjawisk, ukazując je w ostrej, niekiedy niemal karykaturalnej, formie. Nie znaczy to jednak - i nie chcemy tego twierdzić - iż są one osobliwością polską ostatnich lat.

Co więcej - i chcemy to mocno podkreślić - wiele $z$ charakterystycznych i uderzających dziś w Polsce zjawisk w ogóle nie jest polską osobliwością. Podejmując ich analizę chcielibyśmy uniknąć tak częstego dziś w polskiej socjologii i publicystyce społecznej, w myśleniu o zjawiskach społecznych wąskiego polonocentryzmu, fascynacji domniemaną unikalnością i niepowtarzalnością zjawisk zachodzących w „polskim laboratorium”. Wiele z tych zjawisk i procesów odnaleźć można także $\mathrm{w}$ innych typach społeczeństw i kultur, odległych w czasie i przestrzeni, o odmiennych tradycjach, odmiennych doświadczeniach i uwarunkowaniach. Dzięki temu można zobaczyć je w nowym świetle, posta-

PIERWOĐRUK w: Edmund Wnuk-Lipiński (red.), Grupy i więzi społeczne w systemie monocentrycznym, IFiS PAN, Warszawa 1990, s. 37-69. 
wić na ich temat nowe hipotezy, a tym samym - lepiej zrozumieć. Dlatego w naszym artykule będziemy stosować perspektywę porównawczą, odwołując się do dorobku antropologii i wykorzystując powstałe w jej ramach koncepcje interpretacyjne. Nie jest to praktyka często stosowana we współczesnej polskiej socjologii, która wbrew okolicznościowym deklaracjom i postulatom współpracy z dyscyplinami pokrewnymi, i wbrew własnym tradycjom badawczym, w analizie współczesnego społeczeństwa polskiego zbyt często pozostaje w wąskich ramach profesjonalnych, ograniczając się do perspektywy „tu i teraz".

Przy całej bardzo prezentystycznej orientacji polskiej socjologii docenia się — przynajmniej w sferze deklaracji - potrzebę uwzględniania „współczynnika historycznego" (jak go kiedyś określił Piotr Sztompka) przy analizie zjawisk społecznych i bieżącej rzeczywistości społecznej. Uwzględnienie natomiast perspektywy antropologicznej nie jest nawet postulatem; w ogóle nie jest przedmiotem refleksji i samoświadomości polskich socjologów. Ta różnica wydaje się znamienna.

Cóż to jest - perspektywa antropologiczna? Różnie ją można rozumieć1. Dla nas najistotniejsze jest spojrzenie na własne społeczeństwo, własną kulturę z perspektywy wiedzy o innych, z perspektywy innego typu społeczeństwa, innego typu kultury. Perspektywa ta stwarza możliwość zrozumienia własnego społeczeństwa - zrozumienia lepszego, bądź też zrozumienia w ogóle. Przyjęta w naszej analizie perspektywa porównawcza pozwala - jak sądzimy - na uchwycenie pewnych zjawisk i mechanizmów, które są pomijane lub co najmniej nie w pełni uwzględniane w analizach socjologicznych.

Obok próby zastosowania perspektywy antropologicznej odwołamy się też do perspektywy węższej. Przywołując wyniki badań innych krajów realnego socjalizmu, postaramy się postawić kilka hipotez o charakterze systemowym. Będziemy poszukiwać korzeni obserwowanych zjawisk w strukturze i logice działania polityczno-gospodarczych systemów socjalizmu.

Szkic ten pisaliśmy z bardzo umiarkowanymi ambicjami. Chcemy w nim postawić może nawet nie hipotezy, lecz raczej zestaw pytań na temat pewnych istotnych zjawisk współczesnej rzeczywistości polskiej. Jest to więc w pewnym sensie konspekt problematyki, którą zamierzamy w przyszłości rozwinąć.

\section{ŚWIAT WIĘZI NIEFORMALNYCH}

Jedną z niekwestionowanych charakterystycznych cech polskiej rzeczywistości społecznej, na którą się powszechnie wskazuje począwszy od lat siedemdziesiątych, jest ostry dualizm: rozdzielenie świata prywatnego i publicz-

${ }^{1}$ Elżbieta Tarkowska, Wspótczesna socjologia polska wobec antropologii, czyli perspektywy i ograniczenia antropologii Polski wspótczesnej, „Kultura i Społeczeństwo” 1990, nr 3. 
nego, rzeczywistego i oficjalnego, „świata ludzi” i „świata instytucji” ${ }^{2}$. Jego pochodną jest zjawisko dymorfizmu wartości, opisane przez Edmunda Wnuk-Lipińskiego ${ }^{3}$, wyrażające się $\mathrm{w}$ „dwoistości postaw i wartości moralnych w zależności od tego, czy potencjalnym partnerem jest drugi człowiek czy instytucja” oraz w „rozdwojeniu między tym, co ludzie myślą, a tym, co robią" $\mathrm{Z}$ kolei $\mathrm{w}$ sferze więzi społecznych pochodną rozbicia życia społecznego na dwa odrębne światy jest szczególna rola prywatnej sfery życia i szczególna rola nieformalnych powiązań międzyludzkich, struktur nieformalnych. Intensywność, autentyczność, żywość kontaktów charakteryzuje stosunki między ludźmi w sferze prywatnej, w przeciwieństwie do pozorności i fasadowości działań w sferze publicznej, oficjalnej, instytucjonalnej. W związku z tym szczególnie ważna rola przypada małym grupom - rodzinnym, przyjacielskim, towarzyskim. Wiele badań wskazuje na wartości prywatne i prywatno-stabilizacyjne ${ }^{5}$ jako najważniejsze w hierarchii wartości Polaków. Rodzina i życie rodzinne są wartością pojawiającą się niezmiennie na pierwszym miejscu w badaniach systemów wartości, świadomości społecznej, stylu życia. Okresy ożywienia politycznego, autentycznego uaktywnienia i uspołecznienia publicznej sfery życia (ostatnio w latach 1980-1981) to jednocześnie okresy relatywnego zmniejszenia roli rodziny i prywatnej sfery życia $\mathrm{w}$ życiu codziennym Polaków, w ich aspiracjach i planach na przyszłość ${ }^{6}$. Lata osiemdziesiąte, po wprowadzeniu stanu wojennego, to okres powrotu wartości prywatno-stabilizacyjnych i ponownego wzrostu znaczenia rodziny i prywatnej sfery życia w życiu codziennym i w świadomości społecznej. Mówi się wprost o „wycofywaniu się społeczeństwa polskiego do małych grup" opartych na więziach nieformalnych, co jest wyrazem ograniczenia sfery istotnych zaangażowań do takiej przestrzeni społecznej, w ramach której ma się wpływ na bieg wydarzeń. Mówi się dziś o „prywatyzacji” orientacji przeważającej w społeczeństwie polskim, o „prywa-

\footnotetext{
${ }^{2}$ Stefan Nowak, Wartości i postawy społeczne, w: Systemy wartości a wzory konsumpcji społeczeństwa polskiego (praca zbiorowa), Warszawa 1980.

${ }^{3}$ Edmund Wnuk-Lipiński, Dimorphism of Values and Social Schizophrenia: A Tentative Description, „Sisyphus” 1982, t. 3.

${ }^{4}$ Stefan Nowak, Wartości i postawy społeczne, cyt. wyd. Jest rzeczą charakterystyczną, że identyczne lub bardzo zbliżone koncepcje wysunęli inni badacze krajów socjalistycznych. Korespondent „New York Times” w Moskwie opisywał obserwowane społeczeństwo w kategoriach „schizofrenii społecznej” (Hedrick Smith, The Russians, New York 1976); o „schizofrenicznym rozdwojeniu życia” w okresie stalinowskim pisał Zdeněk Mlynář (Mróz od Wschodu, 1981); Elmer Hankiss (The „Second Society". Is There a Second Social Paradigm Working in Contemporary Hungary? Budapest 1986) mówi o podwójnej lub rozszczepionej świadomości; Yuri Glasov (The Russian Kind since Stalin's Death, Dordrecht 1985) o behawioralnym bilingualizmie; Milan Simecka (The Restoration of Order: The Normalization of Czechoslovakia, London 1984) o życiu w kłamstwie.

${ }_{5}^{5}$ Ten drugi termin lepiej oddaje charakterystyczne zawężenie perspektywy nie tylko przestrzeni społecznej (sfera prywatna), ale i czasu społecznego.

${ }^{6}$ Stefan Nowak, Dylematy i antynomie świadomości społecznej drugiej połowy lat osiemdziesiątych, w: Jerzy J. Wiatr (red.), Zaspokajanie potrzeb w warunkach kryzysu, Warszawa 1986.
} 
tyzacji” życia społecznego w różnych dziedzinach, a nawet o „społeczeństwie prywatnym" 7 .

Cechą charakterystyczną tego typu strukturalizacji życia społecznego nie jest rodzina nuklearna, lecz „mała grupa”, „mikrostruktura”, połączona bezpośrednimi więziami, grupa niejako obudowana wokół rodziny, poszerzona o więzi przyjacielskie, koleżeńskie, sąsiedzkie. Na swoiste novum, jakim jest zjawisko znaczącego poszerzania (zwłaszcza na terenie zakładów pracy) własnej małej grupy w wyniku doświadczeń lat 1980-1981, wskazują Jadwiga Koralewicz i Edmund Wnuk-Lipiński ${ }^{8}$. Grupy te nie pełnią już — lub nie tylko — funkcji ucieczkowych i kompensacyjnych, są jakby bardziej otwarte na zewnątrz.

Bo w owym czasie, w okresie stanu wojennego, działały jednocześnie silne czynniki integrujące. Pamięć czasów „Solidarności”, a może w jeszcze większym stopniu traumatyczne doświadczenie wprowadzenia stanu wojennego, umocniły „kręgi wzajemnego zaufania” i więzi międzyludzkie. Z jednej strony więc dało się obserwować jakby instynktowne wycofanie się do sfery prywatnej — rodziny i kręgów przyjaciół, z drugiej zaś pojawiło się interesujące zjawisko rozbudowy alternatywnej sfery publicznej, w znacznej mierze tworzonej właśnie w oparciu o prywatne, bezpośrednie więzi. Podstawową tkankę powstałego po grudniu 1981 roku podziemia stanowiły kręgi „swoich ludzi”, powiązanych osobistymi więziami o charakterze rodzinnym, koleżeńskim, zawodowym czy sąsiedzkim. Jednocześnie bojkot sfery publicznej, odmowa udziału w życiu publicznym, udział w masowych demonstracjach - były czynnikiem społecznej integracji szerokich rzesz.

Ale jednocześnie cały okres lat osiemdziesiątych to okres przedłużającego się kryzysu ekonomicznego, trudnych warunków życia codziennego, niedoborów rynkowych, pauperyzacji znacznych mas naszego społeczeństwa. Sytuacja ta niewątpliwie eksponuje rolę rodziny i w centrum zainteresowań i działań jednostek stawia rozliczne zabiegi wokół zapewnienia rodzinie dotychczaso-

7 Grażyna Gęsicka i in., Szanse i warunki ugody społecznej (Ekspertyza Zarzadu Oddziału Warszawskiego PTS), w: Edmund Wnuk-Lipiński (red.), VII Ogólnopolski Zjazd Socjologiczny. Materiały, Warszawa 1987, s. 664-665. Ten stan rzeczy potwierdzają badania opinii publicznej. Stanisław Kwiatkowski, dyrektor Centrum Badań Opinii Społecznej, stwierdził: „Mamy w społeczeństwie inny rodzaj zagrożenia. Już nie rebelię, nie apatię, lecz prywatyzację w imię zawołania "ratuj się, kto może». Coraz więcej zwłaszcza prężnych, młodych ludzi dystansuje się od zbiorowego działania, postanawia sobie radzić na prywatny rachunek, ma zamiar kształtować swój los poza losami ogółu" (S. Kwiatkowski, Wypowiedź na posiedzeniu Rady Konsultacyjnej, „Rada Narodowa”, wyd. spec., nr 2, 16 kwietnia 1987). Podobnie twierdzi Mirosława Marody: „[...] przedsiębiorczość społeczeństwa polskiego jest zaradnością jednostek i grup [...]. Zaradność nakierowana jest przede wszystkim na zmianę położenia jednostki lub grupy w systemie gospodarczym, a nie na zmianę tego systemu. Jej ogólną dewizą jest: bronić swego i wyrwać, co się da, dla siebie, z tego, co jest" (Mirosława Marody, Między wspótpraca a odrzuceniem, „Polityka”, 11 lipca 1987).

${ }^{8}$ Jadwiga Koralewicz, Edmund Wnuk-Lipiński, Wizje społeczeństwa, zróżnicowań $i$ nierówności w świadomości zbiorowej, „Studia Socjologiczne” 1987, nr 2. 
wego poziomu życia. Sytuacja długotrwałego kryzysu i permanentnie ograniczonej puli dóbr w szczególny, karykaturalny może nawet sposób wyostrza rolę rodziny i własnej małej grupy w przeciwstawieniu do obcej, niekiedy zagrażającej, rzeczywistości zewnętrznej. Trudne warunki życia, uciążliwość, zmęczenie, niepewność jutra niekoniecznie skłaniają do współpracy, lecz także - a może przede wszystkim - do rywalizacji; ich efektem mogą być nie tylko więzi, ale i nowe obszary konfliktów, nowe postaci agresji. Rodzina, mała grupa, sieć powiązań nieformalnych - to nie tylko wspólnota więzi i poczucie bliskości, to nie tylko wartości afiliacyjne. Mogą one również działać dezintegrująco w stosunku do szerszych struktur społecznych, wyrażać egoizm, wąski interes (zawężony zarówno w przestrzeni społecznej, jak i w czasie społecznym: ważny jest mój doraźny interes), prowadzić do rywalizacji i agresji. Zapewne nie byłoby trafne określenie społeczeństwa polskiego jako „społeczeństwa zatomizowanych rodzin nuklearnych", jak się charakteryzuje współczesne społeczeństwa industrialne. Ale czy nie jest to społeczeństwo zatomizowanych małych grup, „mikrostruktur”, „sieci powiązań nieformalnych”, rywalizujących ze sobą, wzajemnie sobie obcych, a nawet wrogich, o sprzecznych interesach i specyficznie indywidualistycznej ${ }^{9}$ i egoistycznej orientacji?

Ten aspekt zjawisk wydaje się niedoceniony bądź wręcz pomijany przez badaczy opisujących w połowie lat osiemdziesiątych społeczeństwo polskie. $\mathrm{Z}$ ich prac wyłania się pewien niespójny i niekonsekwentny obraz rzeczywistości społecznej.

Otóż z jednej strony wskazuje się na szczególną strukturalizację społeczeństwa w postaci zbioru rozszerzonych małych grup obudowanych wokół rodziny, powiększonych o więzi przyjacielskie, sąsiedzkie, koleżeńskie. Z drugiej strony wskazuje się na wzrost agresji, niechęci i napięć w stosunkach między ludźmi. Ale te dwa punkty widzenia nigdzie się nie spotykają. W rezultacie powstaje niekoherentny obraz społeczeństwa polskiego — obraz agresywnych, niechętnych sobie, niekiedy wrogich jednostek, a z drugiej strony - ciepłych, podtrzymujących, silnie emocjonalnie powiązanych mikrostruktur — rodziny, przyjaciół i znajomych, które „przetrwały próby rozbicia i atomizacji społeczeństwa” i bywają „budulcem” dla szerszych struktur społecznych. Podkreśla się funkcje integracyjne owych mikrostruktur, są one przedstawiane jako swego rodzaju ostoja narodu, jako prawdziwa wspólnota, obszar autentycznego życia społecznego i autentycznych więzi społecznych. Świadczy o tym choćby język, jakim się je charakteryzuje: „Silnie emocjonalne więzi w obrębie małych grup stanowią jedna $z$ istotnych podstaw trwania społeczeństwa polskiego. Różnego rodzaju trudne sytuacje i kłopoty, frustracje i bezsilności są przez

\footnotetext{
${ }^{9}$ Chodzi tu o rozszerzony na rodzinę i małą grupę indywidualizm; indywidualizm „ponadosobisty”, „napęczniały”, rozumiany jako „tendencja do zasklepiania się w elementarnych grupach podstawowych" (Adam Podgórecki, Całościowa analiza społeczeństwa polskiego, w: VII Ogólnopolski..., cyt. wyd., s. 596).
} 
Polaków przezwyciężane głównie przy pomocy rodziny, przyjaciół, bliskich kolegów i znajomych" ${ }^{10}$. W tym wyidealizowanym obrazie rodziny i małej grupy, skoncentrowanym na jej funkcjach integracyjnych, nie ma miejsca na negatywne zjawiska życia społecznego, realizującego się w (oraz przez) mikrostrukturach. Nie ma miejsca, lub jest go bardzo niewiele, na zjawiska degeneracji więzi nieformalnych w konsumpcyjnej rywalizacji w życiu codziennym, w efekcie wieloletniego kryzysu i permanentnych niedoborów rynkowych ${ }^{11}$, na zjawiska agresji, korupcji i inne objawy patologii społecznej.

Owe „idealizacje”, czy może ściślej — koncentrowanie się na pozytywnej stronie zjawisk, pochodzą stąd, iż owe „małe grupy”, „mikrostruktury” przeciwstawia się państwu i zinstytucjonalizowanej sferze życia społecznego. Postrzega się je przede wszystkim w płaszczyźnie życia politycznego, w wymiarze potrzeb i świadomości obywatelskiej. A przecież to nie wyczerpuje wszystkiego. Oprócz państwa jest jeszcze społeczeństwo, czyli inni ludzie, inne mikrostruktury. Wskazuje się dziś na wzrost agresji, brak życzliwości, wzajemną niechęć w kontaktach między ludźmi, a nie - między ludźmi a światem instytucji. $\mathrm{Z}$ perspektyw życia codziennego, obyczaju, psychologicznego funkcjonowania jednostek na co dzień, „nieprzyjazne społeczeństwo” (znakomity termin, przez Jadwigę Koralewicz i Edmunda Wnuk-Lipińskiego odnoszony właśnie do świata instytucji) to także inni, obcy ludzie, to także inne, obce, zewnętrzne mikrostruktury. Wprawdzie, jak się wydaje, łatwo w naszym społeczeństwie sforsować tę barierę obcości, ale ona istnieje i funkcjonuje w sposób wyraźny.

$\mathrm{W}$ naszej analizie chcemy iść $\mathrm{w}$ tym właśnie kierunku: nie ograniczać się do integracyjnych funkcji małych grup, lecz próbować opisać je pełniej, bardziej wszechstronnie. Twierdzimy, że charakterystyczną cechą życia społecznego w Polsce połowy lat osiemdziesiątych jest nie tylko jego szczególna strukturalizacja $\mathrm{w}$ postaci małych grup, mikrostruktur, sieci powiązań nieformalnych skupionych wokół rodziny i/lub innych małych grup (koledzy z pracy, sąsiedzi, przyjaciele, znajomi), ale ponadto że owe małe grupy stanowią podstawową jednostkę strategiczną, wyznaczającą krąg „swoich” i „obcych”, wytyczają obszary stosowania odmiennych norm i zasad.

Sądzimy więc, że właśnie dziś warto spojrzeć na społeczeństwo polskie z perspektywy podziału na „swoich” i „obcych”, będącego czymś innym niż podział „my-oni”, odnoszony do sfery polityki, władzy, potrzeb obywatelskich. Uwzględnienie podziału rzeczywistości społecznej na „swoich” i „obcych”, narzędzie stosowane raczej przez antropologów niż socjologów, obejmuje trudno

10 Jadwiga Koralewicz, Edmund Wnuk-Lipiński, Życie rodzinne, towarzyskie i publiczne. Wartości i deprywacje, w: Edmund Wnuk-Lipiński (red.), Nierówności i upośledzenia w świadomości społecznej, Warszawa 1987, s. 209.

11 Problematyce tej, w płaszczyźnie zarówno empirycznej, jak i teoretycznej, wiele uwagi poświęca Piotr Gliński w niestety nieopublikowanej pracy doktorskiej („Ekonomiczne uwarunkowania stylu życia. Rodziny miejskie w Polsce w latach siedemdziesiątych”, IFiS PAN 1983). 
uchwytną, jednak bardzo ważną, psychiczno-obyczajową sferę relacji między ludźmi. Podział na „swoich” — bliskich, znanych, zrozumiałych, wytyczających uporządkowaną przestrzeń społeczną, rządzoną normami znanymi i jasnymi, oraz na „obcych” — nieznanych, niezrozumiałych, zakłócających istniejący porządek, a niekiedy zagrażających, wydaje się jednym $z$ istotnych dziś podziałów w społeczeństwie polskim, przez socjologów zupełnie nie dostrzeganym.

Sądzimy ponadto, że w odniesieniu do współczesnego społeczeństwa polskiego należy przeformułować zasadę dymorfizmu wartości, obejmującą podział rzeczywistości na sferę prywatną i sferę oficjalną. Warto chyba uzupełnić ją zasadą dualizmu etycznego, związaną z postrzeganiem rzeczywistości społecznej jako podzielonej na „swoich” i „obcych”. W myśl tej reguły „uznaje się pewne zasady moralne za obowiązujące tylko wobec jednostek lub grupy najbliższej danemu osobnikowi, wprost przeciwne zaś postępowanie w stosunku do obcych [...] uchodzi za moralne lub nawet za akt wybitnie dodatni" ${ }^{12}$. Wydaje się, że zjawiska dualizmu etycznego występują w skali masowej w naszym społeczeństwie ${ }^{13}$.

Twierdzimy ponadto, iż takie cechy, jak agresywność, wrogość, niechęć czy rywalizacja, dotyczą nie tylko jednostek. Perspektywę tę należy rozciągnąć na małe grupy. Jak to pisał Adam Podgórecki: „I tak rodzina z tradycyjnej jednostki socjalizującej młode pokolenie przekształciła się w "obronne szańce», ostatnie okopy, za jakie jednostka może się jeszcze legalnie skrywać przed napierającą $z$ zewnątrz demolującą inwazją. Małżeństwo przestaje być romantycznym «spotkaniem» dwóch jednostek, a staje się zawziętym zaczepno-odpornym, zawieranym na całe życie sojuszem" ${ }^{14}$. Jest nieco przesady w tym rysunku (zwłaszcza jeśli chodzi o ten „sojusz na całe życie”), ale w swej ogólnej intencji jest on nam bliski. Z tym zastrzeżeniem, iż w myśl naszej koncepcji nie dotyczy on (bądź nie tylko) małżeństwa i rodziny, lecz różnego rodzaju mikrostruktur.

By podsumować ten fragment naszych rozważań: kilka grup zjawisk, dobrze zresztą opisanych i dobrze zbadanych, wydaje się zjawiskami charakterystycznymi dla współczesnej polskiej rzeczywistości.

Po pierwsze, podział rzeczywistości społecznej na sferę prywatną i publiczną. Problem jest szczególnie dobrze znany, szeroko opisany i komentowany.

Po drugie, charakterystyczne zawężenie przestrzeni społecznej: dominacja w życiu społecznym rodziny, sieci przyjaciół, więzi nieformalnych. Interes rodziny czy małej grupy (mikrostruktury) wyznacza ramę odniesienia działań: niechęć i niezdolność do aktywności na rzecz szerszych zbiorowości. Jest to swego rodzaju rozszerzony indywidualizm czy egoizm, wyrażający się między

12 Kazimierz Dobrowolski, Studia z pogranicza historii i socjologii, Wrocław 1967, s. 58.

${ }^{13}$ Niezwykle wyraziste przykłady tego typu postaw przynosi świetne studium Wojciecha Pawlika Ekonomia życia codziennego społeczności lokalnej, w: Jacek Kurczewski (red.), Umowa o kartki, Warszawa 1985.

${ }^{14}$ Adam Podgórecki, Całościowa analiza społeczeństwa polskiego, cyt. wyd., s. 603. 
innymi (a nie tylko, co bardzo mocno chcemy podkreślić) w opisywanych przez socjologów zjawiskach „familizmu” czy „familiocentryzmu”.

Po trzecie, równie charakterystyczne wydaje się zawężenie czasu społecznego do orientacji prezentystycznej: koncentracja na teraźniejszości i natychmiastowości, niechęć i niemożność planowania, myślenia i działania w kategoriach odległych celów, skrócenie perspektywy przyszłości, priorytet doraźności, krótkotrwałości, a co za tym idzie - bylejakości, między innymi w sferze stosunków między ludźmi. Taka orientacja prezentystyczna charakteryzuje ludzi i grupy znajdujące się w różnego rodzaju sytuacjach zależności i przymusu: ekonomicznego, społecznego, politycznego czy jakiegokolwiek innego; jest sposobem przystosowania się do niejasności i niepewności stwarzanych przez te sytuacje. Wielu badaczy zwróciło na to uwagę jako na fenomen lat osiemdziesiątych, po wprowadzeniu stanu wojennego. Sądzimy, że jest to zjawisko trwalsze i na głębszym poziomie charakteryzujące stan świadomości społecznej Polaków ${ }^{15}$.

Przestrzeń społeczna i czas społeczny tak zawężone do najbliższego w czasie interesu własnego i interesu rodziny lub małej grupy są wyrazem dezintegracji społecznej, a jednocześnie działają dezintegrująco. To nas prowadzi do czwartego kompleksu zagadnień, a mianowicie do związanych z wyżej wskazanymi zjawiskami postaw i zachowań dezintegracyjnych, konkurencyjnych, agresywnych, do klimatu nieufności i wrogości w stosunkach między ludźmi oraz do stosowania dwoistej etyki - innej do „swoich”, odmiennej wobec „obcych”.

Zjawiska wchodzące w skład tych czterech grup zagadnień, niekiedy bardzo dobrze znane i opracowane, analizowane bywają oddzielnie, postrzegane w pewnej wzajemnej izolacji; proponujemy, by ujać je łącznie. W wypracowaniu tego syntetyzującego punktu widzenia pomocna nam była pewna znana koncepcja antropologiczna.

\section{KONCEPCJA AMORALNEGO FAMILIZMU}

Edward C. Banfield użył terminu „amoralny familizm” do opisu tradycyjnej chłopskiej społeczności włoskiej z biednego, zacofanego okręgu Montenegrano ${ }^{16}$. Banfielda interesowała rola i funkcjonowanie tradycyjnej chłopskiej rodziny, z całą skomplikowaną, szeroko rozbudowaną strukturą, a przede wszystkim jej systemem norm i wartości. System ten wydaje się w wielu momentach zbliżony do obserwowanego dziś w Polsce systemu norm i wartości rodzinnych oraz mikrostrukturowych.

15 Elżbieta Tarkowska, Zróżnicowanie stylów życia w Polsce: pokolenie i płeć, „Kultura i Społeczeństwo" 1985, nr 2; Elżbieta Tarkowska, Niepewność przyszłości $i$ dominacja orientacji prezentystycznej: dawne i nowe elementy stylów życia w Polsce, „Kultura i Społeczeństwo” 1987, nr 3; Mirosława Marody, Antynomie społecznej świadomości, „Odra” 1987, nr 1.

${ }^{16}$ Edward C. Banfield, The Moral Basis of a Backward Society, w: Arnold J. Heidenheimer (red.), Political Corruption: Readings in Comparative Analysis, New Brunswick 1979. 
Mówiąc o zjawiskach familizmu w Polsce anno domini 1988 należy przede wszystkim doprecyzować, jak rozumie się odpowiednik owej „rodziny” banfieldowskiej. $Z$ pewnością bowiem nie chodzi tu o wąsko rozumianą rodzinę nuklearną, a nawet niekoniecznie o rodzinę. W grę mogą wchodzić dwie interpretacje.

Pierwsza dotyczyłaby typu rodziny, który Eugene Litwak określa jako zmodyfikowaną, rozszerzoną rodzinę. Jest ona koalicją rodzin nuklearnych pozostających w stanie wzajemnej zależności. „Jej członkowie wymieniają między sobą ważne usługi, co różni ich od izolowanej rodziny nuklearnej. Cieszą się one (składowe rodziny nuklearnej) znaczną autonomią, co odróżnia ten typ od klasycznej rozszerzonej rodziny [...]. Poszczególne rodziny nuklearne zamieszkują oddzielnie, ale uaktywniają się, gdy potrzebna jest pomoc rodzinna" ${ }^{17}$.

W drugim, szerszym rozumieniu mielibyśmy na myśli sieci nieformalnych powiązań, których trzonem jest rodzina, poszerzonych o kolegów z pracy, przyjaciół, sąsiadów, znajomych. Ważny i wyróżniający jest nieformalny typ stosunków i więzi między ludźmi, wyznaczający obszar „swoich” i „obcych”. Nie chodzi tu więc zawsze o rodziny, ale o wszelkie nieformalne grupy, kierujące się zasadą amoralnego familizmu ${ }^{18}$.

Banfield wysunął koncepcję amoralnego familizmu badając zacofaną, tradycyjną, biedną wieś włoską. $Z$ biedą i zacofaniem wiąże istotne wzory zachowań i wartości tej społeczności, wyrażające charakterystyczne zawężenie percepcji świata i strategii życiowej. Jest to zawężenie zarówno przestrzeni społecznej, jak i czasu społecznego: włoscy chłopi nie są zdolni ani do działania na rzecz wspólnego, szerszego dobra, ani do działania na rzecz dalekosiężnych celów. Tym, co wyznacza ich działanie, jest natychmiastowy, materialny interes rodziny. Jest to więc swoisty, choć nie jednostkowy indywidualizm: indywidualizm rodzinny, jeśli tak można rzec.

Podstawową zasadę amoralnego familizmu Banfield charakteryzuje następująco: „Maksymalizuj doraźne materialne korzyści rodziny zakładając, że wszyscy postępują tak samo. Tego, który postępuje według tej zasady, będziemy nazywać amoralnym familista" "19. Niezwykle istotną cechą amoralnego familizmu jest stosowanie zupełnie odmiennych norm i reguł wobec rodziny i kręgu przyjaciół, a innych w stosunku do wszystkiego, co leży na zewnątrz tego zamkniętego świata. W ramach rodziny ważne są kryteria dobra i zła, które na zewnątrz nie znajdują zastosowania.

W zacofanej społeczności chłopskiej na południu Włoch, tak dalekiej i odmiennej od współczesnego społeczeństwa polskiego, zaobserwowano więc zja-

${ }_{17}$ Eugene Liwak, Extended Kin Relations in an Industrial Democratic Society, w: Ethel Shanas, Gordon F. Streib (red.), Social Structure and the Family, Englewood Cliffs 1965, s. 291.

18 Raz jeszcze chcemy to mocno podkreślić, by uniknąć nieporozumień, do jakich może poniekąd prowadzić sam termin, zaczerpnięty przez nas od Banfielda.

19 Edward C. Banfield, The Moral Basis of a Backward Society, cyt. wyd., s. 123. 
wiska podobne do tych, które określa się jako charakterystyczne czy wręcz specyficzne cechy naszego społeczeństwa ${ }^{20}$. Mamy więc ostry podział na sferę publiczną i prywatną, mamy dominację sfery prywatnej i więzi nieformalnych, mamy charakterystyczne zawężenie czasu społecznego do orientacji prezentystycznej, mamy dymorfizm wartości i dualizm etyczny.

Lektura studium Banfielda jest inspirująca i pouczająca. Ukazuje, iż koncepcja opracowana przy analizie społeczeństwa tak odmiennego pozwala lepiej zrozumieć rzeczywistość nam najbliższą. W tej perspektywie widać wyraźnie, iż warto zastanowić się nad bardziej ogólnymi warunkami, które sprzyjają ukształtowaniu się, pojawieniu lub rozwinięciu zjawisk tak dziś uderzających w Polsce. Warto więc zastanowić się, w jakich to sytuacjach społecznych, ekonomicznych, historycznych, kulturowych pojawiają się zjawiska składające się na syndrom amoralnego familizmu.

Badacze polskiej rzeczywistości odnoszą niektóre $z$ tych zjawisk do dziejów polskich, zmuszających całe pokolenia do „życia na niby” i wysuwających na czoło instytucji społecznych rodzinę i nieformalną sieć powiązań ${ }^{21}$. Inne wyjaśnienia odwołują się do kompleksu zjawisk takich jak sytuacja niedoborów ekonomicznych, z jednej strony prowadząca do rozpowszechnienia się korupcji, nieformalnych mechanizmów gospodarczo-politycznych, rozwoju drugiej gospodarki itp., a z drugiej strony - sprzyjająca tworzeniu się i umacnianiu percepcji świata $\mathrm{w}$ kategoriach ograniczonych dóbr, kształtująca stosunki interpersonalne nacechowane wzajemną nieufnością, wrogością i zawiścią. Można tu odwoływać się do takich zjawisk jak ubóstwo z całą jego specyficzną kulturą ${ }^{22}$. Poszukując dalszych wyjaśnień można i należy wspomnieć o roli tradycji chłopskiej i zjawiskach "chłopienia miast” (inni badacze mówią w tym przypadku elegancko o „ruralizacji” miast), to znaczy występowaniu właściwego dla tradycyjnej społeczności chłopskiej „kumowsko-kumoterskicgo załatwiania spraw" 23 . Warto uwzględnić obecność tradycyjnych elementów chłopskiej mentalności tak świetnie opisanych przez Ludwika Stommę jako fenomen izolacji świadomościowej, ściśle związanych z postrzeganiem świata społecznego w kategoriach „swoich” i „obcych” ${ }^{24}$. Nie można też wykluczyć jakichś wpływów tradycji szlacheckiej z jej wybujałym indywidualizmem i egoizmem.

20 Podobny pogląd wyraża Kenneth Jowitt (The Leninist Response to National Dependency, Berkeley 1978, s. 72), który stwierdza: „Pod pewnymi względami wizja chłopskiego amoralnego społeczeństwa Banfielda może być przeniesiona do krajów komunistycznych pod nazwą amoralnego społeczeństwa miejskiego".

${ }^{21}$ Adam Podgórecki, Całościowa analiza społeczeństwa polskiego, cyt. wyd.

22 Problematykę kultury ubóstwa omawia Piotr Gliński we wspomnianej pracy; zob. też John K. Galbraith, Istota masowego ubóstwa, Warszawa 1987. Perspektywa ta właśnie dziś wydaje się szczególnie pomocna $\mathrm{w}$ zrozumieniu wielu zjawisk związanych z procesami pauperyzacji znacznych odłamów naszego społeczeństwa.

${ }^{23}$ Adam Podgórecki, Całościowa analiza społeczeństwa polskiego, s. 583,

${ }^{24}$ Ludwik Stomma, Antropologia kultury wsi polskiej XIX w., Warszawa 1986. 
Należy także wspomnieć o roli tradycji katolickiej sprzyjającej, jak to ukazuje Dealy, dymorfizmowi wartości, swoistemu indywidualizmowi i nieobecności orientacji zadaniowej ${ }^{25}$. Warto wreszcie pamiętać o roli systemu polityczno-gospodarczego, poprzez pozorność i fasadowość sprzyjającego ostremu dualizmowi i dymorfizmowi wartości, a zarazem przez stwarzaną sytuację uogólnionej zależności (czy wręcz przymusu) prowadzącego do wytworzenia się postaw niepewności, nieprzewidywalności i zawężonej perspektywy czasowej, wraz ze wszystkimi jej konsekwencjami.

Szersze omówienie wszystkich tych czynników wymagałoby dalszych pogłębionych studiów. W tym miejscu możemy szkicowo omówić jedynie niektóre $z$ nich.

\section{ŚWIAT OGRANICZONYCH DÓBR}

Immanentną, strukturalną cechą systemu socjalizmu realnego jest niedostatek dóbr, zjawisko uderzające i jaskrawo widoczne w Polsce ostatnich lat.

Każdy system ekonomiczny jest systemem niedoboru w tym sensie, iż potrzeby wszystkich jednostek systemu nie mogą być w pełni zaspokojone, choć zwykle ogólna pula dóbr w społeczeństwie przewyższa potencjalne zapotrzebowanie. W systemie realnego socjalizmu ta ogólna pula dóbr i usług jest mniejsza niż potrzeby. Ogólny niedobór odczuwany jest powszechnie, we wszystkich sferach zaspokajania potrzeb pojawiają się niedostatki. Permanentna sytuacja powszechnie odczuwanych niedoborów wytwarza szczególne mechanizmy, których zadaniem jest zaspokajanie potrzeb mimo niedoborów: sprzyja ukształtowaniu się egoistycznych zachowań i postaw defensywno-agresywnych wobec otoczenia społecznego. Obserwujemy na co dzień, w różnych sferach życia, w różnych dziedzinach zaspokajania potrzeb jednostek i rodzin, wiele zjawisk agresji, bezpardonowej konkurencji, „przechytrzania” systemu, co jednak obraca się przeciwko innym ludziom zabiegającym o te same ograniczone dobra (np. miejsce w przedszkolu, telefony, mieszkania, zakupy bez kolejki itd.).

Zjawiska te przypominają dokonaną przez George'a Fostera charakterystykę chłopskiej wizji rzeczywistości jako świata ograniczonych dóbr: „chłopi postrzegają swój świat społeczny i ekonomiczny, jak i naturę - całe swoje środowisko - jako świat, w którym wszystkie pożądane rzeczy, takie jak ziemia, bogactwo, zdrowie, przyjaźń i miłość, męskość i honor, szacunek i status, władza i wpływ, bezpieczeństwo i pewność istnieją, jeśli chodzi o chłopów, zawsze w skończonych i za małych ilościach. Te i inne pożądane dobra nie tylko istnieją w skończonych i ograniczonych ilościach, ale w dodatku nie istnieje żaden bezpośredni sposób, który pozwalałby chłopom zwiększać ilość dostępnych dóbr".

${ }^{25}$ Glen C. Dealy, The Public Man: An Interpretation of Latin American and Other Catholic Countries, Amherst 1977. 
Ten sposób postrzegania świata ma niezwykle ważne konsekwencje społeczne: „Jeśli «Dobro» istnieje w ograniczonych ilościach, które nie mogą być zwiększone, [...] wynika $z$ tego, że jednostka i rodzina może poprawić swoją pozycję tylko kosztem innych. Stąd więc wyraźna poprawa czyjejś pozycji w stosunku do któregoś z «Dóbr» jest postrzegana jako groźba dla całej społeczności. [...] Ponieważ nie zawsze istnieje pewność co do tego, kto rzeczywiście traci [...] każda znacząca poprawa jest postrzegana nie tylko jako zagrożenie dla jednostki czy rodziny, ale dla wszystkich jednostek i rodzin" 26 .

Sądzimy, podobnie jak Foster, że nie są to cechy wyłącznie chłopskiej kultury. Obserwacja polskiej rzeczywistości współczesnej wydaje się potwierdzać koncepcję Fostera. Zjawiska agresji, niechęci, nieżyczliwości w stosunkach między ludźmi, upadek norm i zasad w sferze kontaktów przelotnych (i nie tylko) - po części wypływają ze scharakteryzowanej wyżej orientacji, będącej pochodną głębokich i trwałych niedoborów.

Nastawienia i orientacje agresywno-egoistyczne są wzmacniane przez oficjalną propagandę, upowszechniającą od lat wartości egalitarno-populistycznego socjalizmu. Hasła takie jak „wszyscy mamy jednakowe żołądki”, zawołania o "niesłusznym i nadmiernym bogaceniu się" - przeciwstawiające prostych, uczciwych, ciężko pracujących ludzi bogatym kombinatorom przeniknęły głęboko do świadomości społecznej, tworząc zjawiska roszczeniowości, swoistego partykularyzmu, a przede wszystkim „bezinteresownej zawiści”, co jest swoistą esencją orientacji opisanej przez Fostera. Każdy, kto wystaje ponad przeciętność, jest obiektem niechęci, przeradzającej się niekiedy w nienawiść ${ }^{27}$.

\section{WIELKI REDYSTRYBUTOR}

Poszukując korzeni amoralnego familizmu i nastawień związanych z fosterowskim światem ograniczonych dóbr, obok niedoboru jako trwałej cechy systemu odnajdziemy i inne uwarunkowania systemowe. Mamy tu przede wszystkim na myśli swoisty paternalistyczny welfare state, jaki rozbudował się

\footnotetext{
${ }^{26}$ George M. Foster, Peasant Society and the Image of Limited Good, w: Jack M. Potter, May N. Diaz, George M. Foster (red.), Peasant Society, Boston 1967, s. 304.

27 Bezinteresowna zawiść nie jest bynajmniej polską specjalnością. Badania antropologów prowadzone w społecznościach chłopskich dostarczają wielu przykładów tego zjawiska. Richard i Eva Blum tak opisują grecką wieś: „[...] gdy coś dobrego wydarzy się wieśniakowi, inni wieśniacy wyrażają swą zazdrość plotką, krytyką i obmową. Wieśniacy opisują swoje życie jako niełatwe, gdyż każda rodzina współzawodniczy z innymi i zazdrości tym, którzy mogą osiągnąć sukces i szczęście" (R. Blum, E. Blum, Health and Healing in Rural Greece, Stanford 1965, s. 118). Jeden z członków opisywanej przez Oscara Lewisa rodziny meksykańskiej również podaje fakty bezinteresownej zawiści i konkluduje: „Zamiast starać się podnieść wzajemnie na duchu, naszym hasłem jest: Jak sam jesteś zerem, to niech ten drugi poczuje się przy tobie kanalią. Tak, u nas zawsze musisz się czuć kimś wyższym" (O. Lewis, Sanchez i jego dzieci, Warszawa 1964, s. 485).
} 
po śmierci Stalina w krajach socjalistycznych ${ }^{28}$. Opiera się on na niepisanym kontrakcie społecznym, w myśl którego rządzeni podporządkowują się rządzonym w zamian za patrymonialistyczną opiekę i bezpieczeństwo społeczne. Państwo zwalnia obywateli z konieczności podejmowania ryzyka, działań innowacyjnych, niebezpieczeństw konkurencji, dając w zamian (niskiej co prawda jakości, ale bezpłatnie) świadczenia społeczne, takie jak opieka lekarska czy oświata, oraz zapewnia pełne zatrudnienie. Niska wydajność i dyscyplina pracy, biurokratyczna rutyna blokująca innowacyjność i przedsiębiorczość, niskie morale i etyka pracy powodują, że żartobliwe stwierdzenie „My udajemy, że pracujemy, oni udają, że nam płacą” jest celną syntezą stanu rzeczy.

Ten niepisany kontrakt społeczny wraz z permanentnymi niedoborami i słabym lub nieistniejącym rynkiem stawia państwo w roli Wielkiego Redystrybutora, który dzieli ograniczone dobra według własnych kryteriów oraz w wyniku gier i nacisków prowadzonych w strukturach władzy i gospodarki. Upowszechnia się, jako bardziej racjonalna, „orientacja redystrybucyjna”, przeciwstawna „orientacji produkcyjnej”, a wraz z nią przekonanie, że praca i własny wysiłek nie prowadzą do uzyskiwania pożądanych dóbr i wartości. Jak pisze Wojciech Pawlik, na podstawie badań przeprowadzonych w społeczności lokalnej: „W świadomości społecznej bogactwo prawie zawsze kojarzy się z nieuczciwością lub co najmniej z tzw. sprytem życiowym [...] rzadko natomiast z solidną, wytężoną pracą, zwłaszcza wykonywaną w ramach zatrudnienia w instytucjach gospodarki uspołecznionej" 29.

Także wielu innych badaczy potwierdza prawdę dostępną potocznemu doświadczeniu, o „całkowitej dewaluacji pracy w sektorze państwowym w roli czynnika wyznaczającego materialny dobrobyt rodziny i jednostki" ${ }^{30}$. Jednej z głównych przyczyn tego stanu rzeczy należy upatrywać w słusznym przekonaniu, że w warunkach opisanego wyżej kontraktu społecznego i systemu redystrybucji racjonalna strategia indywidualnych i grupowych działań polega na odwołaniu się do „dojść”, „chodów”, „układów” pozwalających nie tylko łatwiej uzyskać pożądane dobra z puli Wielkiego Redystrybutora niż drogą wytężonej pracy i wzmożonego wysiłku, ale często jest to jedyna droga uzyskania dobra występującego w ograniczonych, niewystarczających ilościach.

Wielu badaczy wskazywało na fakt, że w takim systemie rywalizacja o ograniczone dobra ma charakter pośredni. Jednostki i grupy walczą o wpływy i wy-

${ }^{28}$ Ferenc Fehér, Paternalism as a Mode of Legitimation in Soviet-type Societies, w: T. H. Rigby, Ferenc Fehér (red.), Political Legitimation in Communist States, London 1982, s. 66.

29 Wojciech Pawlik, „Gospodarka lokalna w perspektywie życia codziennego”, 1985 (maszynopis powielony). Uderza i tym razem podobieństwo do spostrzeżeń poczynionych przez badacza włoskiego chłopstwa, który pisał: „Chłop włoski stracił wiarę w siebie, jak i w rząd i swą własną grupę. Mocno wierzy, że ci nieliczni, którzy coś osiągnęli, doszli do tego z jakichś dziwnych powodów: ktoś znalazł ukryte skarby, ktoś wygrał na loterii, innego zaprosił bogaty wujek z Ameryki" (Friedrich G. Friedmann, The World of „La Miseria”, w: Peasant Society, Boston 1967, s. 329).

${ }^{30}$ Mirosława Marody, Antynomie społecznej świadomości, cyt. wyd., s. 4. 
wierają nacisk na redystrybucyjne agendy państwa nie mając pełnej świadomości istnienia konkurentów do tych dóbr. W takiej sytuacji pretensje i żądania kierują się ku państwu - Wielkiemu Redystrybutorowi, a nie ku konkurentom o jego względy ${ }^{31}$. Trudno temu rozumowaniu odmówić racji. Jednocześnie jednak dojmujące braki i niedobory uruchamiają „wizję ograniczonych dóbr" i towarzyszące tejże postawy zawiści i zazdrości. Rodzi to zgeneralizowaną niechęć i agresję skierowaną częściowo przeciw państwu - szafarzowi dóbr, ale także przeciw w praktyce wszystkim współobywatelom, gdyż każdy jest potencjalnym konkurentem do ograniczonej puli dóbr. Na tym tle szczególnie silnie występuje, opisana wyżej, zawiść w stosunku do tych, którym się dobrze powodzi. I trudno się tym postawom dziwić. Skoro w powszechnym przekonaniu warunkiem powodzenia jest sprawnie użyte „dojście” i „chody”, powodzenie materialne musi mieć źródło w nienależnych przywilejach, nielegalnych operacjach, oszustwach i korupcyjnych praktykach. Niechęć szerokich rzesz społeczeństwa kieruje się więc przeciw wszystkim, którzy wykraczają poza przeciętny standard materialny - czy są to przedstawiciele sektora prywatnego, czy ludzie władzy korzystający z różnych przywilejów. O tych właśnie zjawiskach myślał Winicjusz Narojek, gdy pisał o: „[...] rozdwojeniu społecznego odniesienia w ocenie własnego położenia, gdzie, zamiast jednoznacznie skierowanego na przeciwnika antagonizmu, pojawia się zawiść w stosunku do tych, których potrzeby są w mechanizmie życia zbiorowego lepiej zaspokajane, oraz pretensje do szafarza wspólnie wytwarzanych dóbr" ${ }^{32}$. Znów widać tu analogie do postaw opisywanych przez antropologów, szczególnie przez badaczy społeczności chłopskich.

\section{POCZUCIE BRAKU KONTROLI}

Jak zapowiedzieliśmy wcześniej, nie mamy ambicji udzielania ostatecznych odpowiedzi na temat źródeł opisywanych wyżej stanów świadomości i zachowań. Pokusimy się jednak o postawienie kilku hipotez, starając się przy tym wykraczać poza polskie opłotki i wskazywać na bardziej uniwersalny charakter omawianych zjawisk.

U źródeł „wizji ograniczonych dóbr” i syndromu amoralnego familizmu, obok gospodarki niedoboru, leży niewątpliwie poczucie braku kontroli nad rzeczywistością, poczucie zależności, braku wpływu na swoje życie. Nastawienie to kształtuje się, jak pokazują badania, w dwóch typach sytuacji. Po pierwsze $\mathrm{w}$ takich, które są nieprzewidywalne $z$ racji zmienności, niestabilności, nieregularności wydarzeń (np. wojny, gwałtowne kryzysy). Po drugie, w takich,

${ }^{31}$ Włodzimierz Wesołowski: Klasy, warstwy i władza, Warszawa 1966, s. 193; Winicjusz Narojek, Struktura społeczna $w$ doświadczeniu jednostki. Studium $z$ socjologii wspótczesnego spoteczeństwa polskiego, Warszawa 1982, s. 168-171.

32 Tamże, s. 171. 
w których nieprzewidywalność wiąże się z brakiem kontroli, ze względu na brak wpływu, zależność, podporządkowanie. Zwraca na to uwagę Foster, włączając do „wizji świata ograniczonych dóbr” poczucie, że: „nie tylko pożądane dobra istnieją w skończonych i ograniczonych ilościach, ale nie istnieje żaden bezpośredni sposób, który pozwalałby chłopom zwiększyć ilość dostępnych dóbr" ${ }^{33}$.

W Polsce i innych krajach socjalistycznych poczucie to rodziła i rodzi centralistyczna i niedemokratyczna logika systemu polityczno-gospodarczego, wywołująca poczucie, że najważniejsze decyzje podejmowane są gdzieś na górze, w bliżej nieokreślonych miejscach, przez bliżej nieokreślonych ludzi i wszystko, co się dzieje, szczególnie to wszystko, co wykracza poza sferę czysto prywatną, dzieje się za sprawą sił i mechanizmów pozostających poza wszelką kontrolą i wpływem jednostki czy jej bezpośredniej nieformalnej grupy. Stąd już tylko krok do: „przekonania, że człowiek nie ma co liczyć na wspólne wraz z innymi dochodzenie do lepszego, wyższego standardu życia, wybiera swoją drogę indywidualną, postanawia radzić sobie sam, mniejsza o innych, nawet kosztem innych" 34 .

Postrzeganie rzeczywistości jako nietypowej i nieprzewidywalnej prowadzi do wycofania się do takiej przestrzeni społecznej i ograniczenia się do takiego czasu społecznego, w ramach którego ma się pewien wpływ na przebieg wydarzeń. W rezultacie więc prowadzi to do dominacji egoistycznego natychmiastowego interesu własnej grupy.

Dodatkowym czynnikiem wpływającym destrukcyjnie na etykę pracy, stosunek do prawa i przepisów oraz wzmacniającym dualizm etyczny jest problem własności. Abstrakcyjna i niedookreślona własność społeczna traktowana jest jako własność niczyja, czy może raczej nie jest w ogóle traktowana jako własność. Z jednej więc strony wzmaga to poczucie alienacji, poczucie, że nie tylko nie kontroluje się rzeczywistości, ale że środek kontroli jest niejasno określony, a drugiej zaś - poczucie, że „społeczne, a więc niczyje”. Rodzi to kolejny dualizm etyczny i relatywizm moralny, polegający na stosowaniu odmiennych norm do własności prywatnej, innych zaś do własności społecznej ${ }^{35}$.

\section{KULTURA I TRADYCJA}

Poszukując korzeni interesujących nas zjawisk kierowaliśmy dotychczas uwagę ku przyczynom systemowym - niedoborom i brakom o charakterze strukturalnym, wynikającym $z$ samej logiki funkcjonowania systemu, oraz ku poczuciu braku kontroli nad rzeczywistością, związanym z niedemokratycznym, autorytarnym charakterem systemu polityczno-gospodarczego. Gdyby-

\footnotetext{
${ }^{33}$ George M. Foster, Peasant Society and the Image of Limited Good, cyt. wyd., s. 304.

34 Stanisław Kwiatkowski, Wypowiedź na posiedzeniu Rady Konsultacyjnej, cyt. wyd.

35 Bardzo interesującą analizę tych problemów, opartą na materiale empirycznym, można znaleźć w: Elżbieta Firlit, Jerzy Chłopecki, Kiedy kradzież nie jest kradzieżą, „Zdanie” 1987, nr 3, s. 6-12.
} 
śmy poprzestali na tych wyjaśnieniach, można by odnieść do nas krytyczne uwagi, z jakimi spotkał się Foster. Słusznie zarzucano mu ekonomiczny determinizm jego koncepcji. Przychylny Fosterowi krytyk John W. Bennett wskazywał, że: „we wszystkich przypadkach zachowań związanych z wizja ograniczonych dóbr musimy założyć istnienie zarówno obiektywnych sytuacji, jak i ich kulturowych wzmocnień" 36 .

Wspomnieliśmy wcześniej $\mathrm{w}$ kontekście interesujących nas problemów o roli tradycji chłopskiej i o procesach „chłopienia miast”. Jeśli uwzględnić fakt, że „nigdy w Polsce, i być może nigdy i nigdzie w Europie, migracje ze wsi do miast nie osiągnęły takich rozmiarów w tak krótkim czasie" 37 , to nic dziwnego, że niejako naturalnie nasuwa się hipoteza o wpływie kultury i tradycji chłopskiej na wartości i postawy współczesnego „amoralnego społeczeństwa miejskiego" w Polsce.

Tezę taką wysuwa między innymi Jacek Wasilewski, który w artykule pod znamiennym tytułem Społeczeństwo polskie, społeczeństwo chtopskie pisze: „Nawyk gromadzenia dóbr (walki o rzeczy) wynikający z chłopskiej nędzy i niepewności losu, kiedy «mieć» oznacza «być», utrwalił się i przetrwał, a wraz z przedstawicielami tej klasy rozprzestrzenił się społecznie" 38 .

Gdyby iść tokiem tego rozumowania, amoralny familizm Polaków oraz postawy i zachowania związane $z$ wizją ograniczonych dóbr miałyby korzenie w chłopskim rodowodzie większości polskiego społeczeństwa i w trwałości chłopskiej tradycji. Trudno jednoznacznie ustosunkować się do tej tezy. Jej potwierdzenie lub odrzucenie wymagałoby szczegółowych dogłębnych badań. Razi ona jednak pewną jednostronnością, przez pominięcie czynników systemowych.

Ciekawsza wydaje się propozycja Zygmunta Baumana. Pisząc na temat klientelizmu w Europie Wschodniej mocno podkreślił wpływ chłopskiej tradycji na kulturę polityczną, kadry i styl życia politycznego w krajach socjalistycznych. Sądzimy, że bez obawy wypaczenia intencji autora można rozszerzyć to twierdzenie na zjawiska przez nas opisywane. Zygmunt Bauman ukazuje jednocześnie niejako drugą stronę medalu, stwierdzając: „Warunki, w jakich stawia się czoło i rozwiązuje życiowe problemy w społeczeństwach komunistycznych, można traktować jako zgeneralizowaną wersję warunków, z jakimi styka się przedindustrialny chłop [...]. Jeśli jako dominującą cechę życia przedindustrialnego chłopa wyróżniliśmy niepewność, pozostaje ona też najdonioślejszą cechą społeczeństwa komunistycznego, następującego po społeczeństwie

${ }^{36}$ John W. Bennett, Further Remarks on Foster's „Image of Limited Good”, „American Anthropologist” 1966, t. 68, nr 1.

37 Kazimierz Piesowicz, Social and Demographic Consequences of World War and the German Occupation in Poland, „Oeconomica Polona” 1983, nr 1.

38 Jacek Wasilewski, Społeczeństwo polskie, społeczeństwo chłopskie, „Studia Socjologiczne” 1986, nr 1, s. 52 . 
chłopskim" ${ }^{39}$. Dalej Bauman wskazuje, że zmieniło się źródło niepewności: nie jest już nim natura, lecz społeczeństwo, a szczególnie brak lub ubóstwo zasad prawnych, które łączyłyby działania z efektem w przewidywalny wzór. W sumie więc, doceniając rolę tradycji chłopskiej, Bauman nie przypisuje jej głównej roli w kształtowaniu postaw i zachowań członków współczesnych społeczeństw Europy Wschodniej. Natomiast tradycja ta wzmacnia i wspiera postawy i zachowania wyrosłe na gruncie warunków innych niż te, w których kształtowała się tradycyjna kultura chłopska. Wzmocnienie to jest tym silniejsze, że nowa rzeczywistość ma szereg cech charakterystycznych dla tradycyjnego społeczeństwa chłopskiego, takich jak niepewność, brak kontroli nad otoczeniem, ostry niedostatek zasobów i związana z nim „wizja świata ograniczonych dóbr”.

Pisząc we wstępnych partiach tego artykułu o rozdzieleniu świata prywatnego i publicznego skupiliśmy uwagę na świecie prywatnym: małej grupie nieformalnej i powstających w jej łonie postawach amoralnego familizmu. W skład syndromu nazwanego przez Banfielda amoralnym familizmem wchodzą też specyficzne postawy w stosunku do państwa czy, generalnie, świata instytucji oficjalnych. Banfield wskazuje na takie poglądy rozpowszechnione w społeczeństwie "amoralnych familistów” jak to, że każda grupa znajdująca się u władzy jest egoistyczna i skorumpowana, że zajmowanie się przez zwykłych obywateli sprawami publicznymi jest nienormalne, a nawet niewłaściwe i że urzędnicy nie mają poczucia identyfikacji $z$ instytucją i wkładają $\mathrm{w}$ swoją pracę tylko tyle wysiłku, ile jest niezbędne do utrzymania stanowiska lub uzyskania awansu ${ }^{40}$.

Postawy niechęci, nieufności, a nawet nienawiści do świata instytucji oficjalnych nie są więc polską specjalnością i pojawiają się w bardzo różnych miejscach i warunkach. Oprócz Banfielda inni badacze stosunków włoskich również wskazują na tego typu postawy rozpowszechnione nie tylko na południu Włoch. Postawy te stanowią typowy składnik tradycyjnej kultury chłopskiej. Pokazuje to na przykład Jowitt na podstawie doświadczeń rumuńskich ${ }^{41}$. Idzie on podobnym tropem co Bauman stwierdzając, że tradycyjna niechęć i obawa przed państwem i jego agendami wzmacnia negatywne postawy wyrosłe już na gruncie nowych doświadczeń. Jednocześnie tradycyjne sposoby radzenia sobie ze światem instytucji formalnych zostały zaadaptowane jako formy ochrony i obawy przed wszechogarniającą inwazją państwa w powojennej Rumunii.

39 Zygmunt Bauman, Comment on Eastern Europe, „Studies in Comparative Communism” 1979, t. 12 , nr 2-3, s. 185.

${ }^{40}$ Edward C. Banfield, The Moral Basis of a Backward Society, cyt. wyd., s. 130, 132, 136.

${ }^{41}$ Kenneth Jowitt, An Organizational Approach to the Study of Political Culture in Marxist-Leninist Systems, „The American Political Science Review” 1974, t. 68, nr 3, s. 1171-1191. Por. Steven L. Sampson, Society without the State in Romania: The Rise of Public Man? (materiał powielony z konferencji „After the Fall: Post Ceausescu Romania at the End of the Twentieth Century”, University of Nebraska, 25-28 października 1986). 
Jeśli chodzi o Polskę, to powszechnie wskazuje się na to, że podejrzliwy i niechętny stosunek do instytucji oficjalnych, nieposzanowanie prawa itd. mają swe źródło w doświadczeniach historycznych, przede wszystkim z okresu rozbioru Polski, gdy przez blisko 150 lat wszelkie urzędy, sądy i wojsko były instytucjami obcego ucisku i narodowej opresji. Postawy te uległy prawdopodobnie wzmocnieniu podczas okupacji niemieckiej w czasie drugiej wojny światowej, gdy bojkot i sprzeciw wobec wszelkich instytucji okupanta traktowano jako patriotyczny obowiązek. Kazimierz Wyka w zbiorze szkiców Życie na niby podjął analizę długotrwałych i głębokich skutków tego rodzaju postaw ${ }^{42}$. Powojenne doświadczenia Polaków ze światem instytucji oficjalnych nie sprzyjały likwidacji tych postaw, a raczej odwrotnie, umacniały je, potwierdzając przekonanie, że świat publiczny jest światem jeśli nie wrogim, to obcym i nieprzyjaznym.

Nie jesteśmy oczywiście w stanie określić, ile w „amoralnym” stosunku do świata instytucji jest tradycji, a ile efektów bezpośrednich doświadczeń współczesnych Polaków. Nie negując siły i znaczenia tradycyjnych postaw i wzorów zachowań zauważmy, że blisko 45-letni okres doświadczeń z instytucjami stalinowskiego i poststalinowskiego systemu jest dostatecznie długi, by powstały i utrwaliły się takie właśnie postawy.

Poszukując źródeł amoralnego familizmu w społeczeństwie polskim możemy w końcu odwołać się do pewnych ogólnych nastawień i wyobrażeń dotyczących wzorów postępowania. Chodzi tu nam o preferowanie nieformalnych (co nie znaczy, że nielegalnych) kontaktów i związków jako podstawy podejmowania decyzji i rozwiązywania problemów. Sieci układów nieformalnych są szeroko wykorzystywane nie tylko przez jednostki i małe grupy w ich walce o większe dochody i rzadkie, trudno dostępne dobra, lecz także przez organizacje gospodarcze, urzędy i społeczności lokalne. Przybierają one bądź to formę poziomych powiązań, bądź to pionowych relacji klient-patron ${ }^{43}$. Indywidualnym aktorom służą one jako efektywny mechanizm uzyskiwania trudno osiągalnych dóbr i usług, a jednocześnie jako smar dla scentralizowanego, skostniałego i nieelastycznego systemu.

Powstaje pytanie, czy tak powszechne rozplenienie się „chodów”, „dojść”, „pleców” i „układów” jest po prostu doraźną odpowiedzią na braki, niedobory i niesprawność instytucji, czy też mamy już do czynienia z głęboko zakorzenionymi postawami i wzorami zachowań.

Problematyką tą zajął się między innymi Terry N. Clark. W artykule The Irish Ethic and the Spirit of Patronage cytuje wypowiedź jednego z szefów policji w Chicago na temat policjantów pochodzenia irlandzkiego. „Najbardziej uderzającą

${ }^{42}$ Kazimierz Wyka, Życie na niby. Szkice z lat 1939-1945, Warszawa 1959.

43 Jacek Tarkowski, Poland: Patrons and Clients in a Planned Economy, w: Shmuel N. Eisenstadt, Rene Lemarchand (red.), Political Clientelism, Patronage and Development, London 1981; Jacek Tarkowski, Patronage in a Centralized, Socialist System: The Case of Poland, „International Political Science Review” 1983, t. 4 , $\mathrm{nr} 4$. 
cechą policjantów-irlandzkich katolików [...] jest zakres, w jakim polegają oni na osobistych lojalnościach i wymianie przysług w załatwianiu spraw. Jeśli nawet istnieje całkowicie legalna, rutynowa droga załatwienia czegoś, można być pewnym, że policjant-irlandzki katolik wybierze jakieś nieformalne środki [...]. Oni świadomie wykraczaja poza formalny system, by załatwić sprawy nieformalnie: czują się lepiej, gdy załatwiają sprawy przez «kontakty», pośredników i przyjaciół" 44 . Dla Polaka ta relacja o egzotycznych policjantach chicagowskich brzmi dziwnie swojsko. Wydaje się, że i u nas pierwszą reakcją wobec najmniejszych nawet trudności jest szybki rachunek dostępnych kontaktów i „chodów”, a nie załatwienie sprawy przez odpowiednie instytucje. Powszechne i długotrwałe posługiwanie się nieformalnymi układami i kontaktami rodzi w końcu pewne trwałe nastawienia i wzory zachowań, które stają się istotnymi elementami kultury grupy czy społeczeństwa, przybierając formę, by użyć terminu Clarka, „etyki”, w tym przypadku „etyki polskiej”.

Nie można jednocześnie wykluczyć, że u podstaw takiej etyki mogą leżeć jeszcze inne elementy kultury, na przykład religia. Cytowany przez Clarka komendant policji mocno podkreślał nie tylko pochodzenie etniczne, ale i katolicyzm swoich podkomendnych. Stwierdził jednocześnie, że policjanci pochodzenia niemieckiego, skandynawskiego czy angielskiego: „mają znacznie większe i bardziej wyraźne przywiązanie do przepisów, standardów i ogólnych zasad jako sposobu postrzegania i załatwiania spraw" ${ }^{45}$. Nie jesteśmy tu w stanie podjąć szerzej tematu wpływu katolicyzmu na interesujące nas zjawiska. Jesteśmy jednocześnie przekonani, że wpływ taki istnieje i sądzimy, że podjęcie takich badań bardzo by wzbogaciło wiedzę o kulturze współczesnego społeczeństwa polskiego. Cennych inspiracji w tym względzie może dostarczyć niedoceniana książka Glena C. Dealy'ego The Public Man, będąca próbą konstrukcji modelu „etyki katolickiej” w takim sensie, w jakim Max Weber mówił o „etyce protestanckiej".

Dealy wskazuje więc na wagę politycznej sfery życia w etyce katolickiej w przeciwieństwie do sfery ekonomicznej, tak istotnej dla protestantyzmu. Charakterystyczna dla tego systemu wartości jest orientacja na przywództwo, aspiracje do władzy i wywyższania się, chęć „bycia wyższym” we wszystkich sferach życia ${ }^{46}$. Odpowiednikiem kapitału, decydującego o wartości człowieka w etyce protestanckiej, w etyce katolickiej jest przyjaźń, sieć przyjaciół. Człowiek etyki katolickiej to człowiek „otoczony ludźmi”. Związki osobiste i kontakty międzyludzkie mają wartość szczególną. W Hiszpanii, jak pisze Dealy, zdobywa się wszystko (pracę, mieszkanie, telefon) dzięki temu, że ma się przy-

\footnotetext{
44 „Ethnicity” 1975, 2, s. 322.

45 Tamże.

46 Przedstawiona przez Dealy'ego etyka katolicka ma wiele cech wspólnych z etosem rycerskim zrekonstruowanym przez Marię Ossowską (Ethos rycerski $i$ jego odmiany, Warszawa 1973).
} 
jaciół. Charakterystyczną cechą etyki katolickiej jest więc dominująca rola rodziny i sieci przyjaciół, które są podstawą siły jednostki.

Inną charakterystyczną cechą etyki katolickiej opisanej przez Dealy'ego jest dualizm: ostre oddzielenie sfery prywatnej i sfery publicznej i towarzyszący temu dymorfizm wartości. Inne zasady obowiązują w bezpiecznym świecie prywatnym, inne w niepewnej, niebezpiecznej sferze publicznej. Tego rozdziału protestantyzm nie zna zupełnie. Dualizm dotyczy również czasu, który w etyce katolickiej ostro oddziela życie codzienne od święta. Codzienna pobożność nie jest ważna: wobec zinstytucjonalizowanej drogi zbawienia wystarczy periodyczne uczestnictwo w mszach. Etykę katolicką w ogóle charakteryzuje szczególny stosunek do czasu, odmienny niż w przypadku etosu purytańskiego. Ważne jest dziś, a nie jutro: nie planuje się przyszłości, lecz używa się teraźniejszości. Nie jest ważna praca (w systemie wartości etyki katolickiej uważana za degradującą), lecz odpoczynek, nie oszczędzanie, lecz ostentacyjna konsumpcja, nie gromadzenie dóbr, lecz ich używanie.

Przedstawiona tu nader skrótowo koncepcja Dealy'ego zasługuje na pewno na pełniejszą prezentację i komentarz. Dla nas w tym miejscu jest przykładem inspiracji do dalszych poszukiwań zjawisk i uwarunkowań społecznych, historycznych, kulturowych sprzyjających ukształtowaniu się interesującego nas fenomenu amoralnego familizmu.

\section{WYSPY INTEGRACJI}

W życiu społecznym Polski współczesnej obserwujemy tendencje zarówno odśrodkowe, jak i wspólnotowe, dezintegrujące, jak i integracyjne. Skupiliśmy uwagę na tych pierwszych, gdyż uważamy, że właśnie one dominują obecnie w życiu codziennym Polaków jako „sposób radzenia sobie z rzeczywistością". Jednak na koniec godzi się wspomnieć o innych formach obrony, polegających na wprowadzaniu do nieuporządkowanej, nieprzewidywalnej rzeczywistości społecznej własnych mechanizmów regulacyjnych i obronnych, w których dominują raczej tendencje integracyjne niż dezintegrujący amoralny familizm. Mamy tu na myśli dążenia do rozbudowy, poszerzenia obszaru „swoich” za pomocą różnego rodzaju form samopomocy, nieformalnych zrzeszeń, oddolnych ruchów alternatywnych itp. Nie jesteśmy tu w stanie podjąć obszerniejszej charakterystyki form. Ograniczymy się więc do przykładów podejmowanych oddolnie inicjatyw, które zasięgiem wykraczają poza rozszerzone rodziny i ścisłe sieci nieformalnych powiązań. W artykule poświęconym takim inicjatywom Jacek Kurczewski wymienia kilka tego typu przedsięwzięć: wykłady organizowane przez różnego typu nieformalne organizacje oświatowe dla różnych środowisk społecznych, niewielkie wspólnoty religijne, komuny młodzieżowe, kluby Anonimowych Alkoholików i ośrodki leczenia narkomanów, grupy mieszkańców społeczności lokalnych protestujących przeciw składowaniu odpadów radioaktywnych czy przeciw plaży dla naturystów (którzy rów- 
nież są tego typu grupą), alternatywne ruchy artystyczne, związki wyznaniowe i sekcje sportowe ${ }^{47}$. Już to wyliczenie, dość chaotyczne i przypadkowe, ukazuje różnorodność „inicjatyw integracyjnych”. Jak się wydaje, obejmują one przede wszystkim ludzi młodych i przez nich są organizowane, choć wiele z tych ugrupowań zrzesza też przedstawicieli starszego pokolenia.

Innym typem organizowanych inicjatyw są ruchy, które zasięg terytorialny i liczba członków pozwała określić jako ruchy masowe. Mamy tu przede wszystkim na myśli „Solidarność”, a szczególnie jej struktury w fabrykach, szkołach czy uniwersytetach. Jakkolwiek jej wpływy i zasięg działania dalekie są od stanu $z$ lat 1980-1981, to nadał stanowi ona ważny element krajobrazu politycznego Polski. W sumie daje się zaobserwować dość znaczne ożywienie polityczne, wyrażające się z jednej strony wzrostem aktywności istniejących organizacji i ugrupowań, z drugiej tworzeniem nowych organizacji i stowarzyszeń. Jednocześnie nie bylibyśmy skłonni przeceniać zakresu i znaczenia tych tendencji. $\mathrm{W}$ różnych kręgach ciągle słyszy się narzekania na bierność i apatię, egoizm i ucieczkę w prywatność. W sumie więc wszystkie wspomniane inicjatywy są tylko małymi wysepkami integracji na szerokich obszarach dezintegracji.

\section{UWAGI KOŃCOWE}

Szukając odpowiedzi na pytanie „Czy Polacy są amoralnymi familistami?”, staraliśmy się wychodzić poza wąską perspektywę „tu i teraz”. Upatrując głównych źródeł opisywanych zjawisk w uwarunkowaniach systemowych, próbowaliśmy uwzględnić oddziaływania czynników innego rodzaju: tradycji, kultury, religii. W wyrywkowy, co prawda, i niesystematyczny sposób wskazywaliśmy na występowanie w zupełnie odmiennych społeczeństwach i kulturach zjawisk podobnych do tych, które wydają się tak specyficzne dla Polski ostatnich lat. Interesowały nas różnego rodzaju uwarunkowania - społeczne, historyczne, kulturowe - sprzyjające ukształtowaniu się zjawisk bliskich amoralnemu familizmowi. Fragmentaryczne, co prawda, odwoływanie się do nich miało oświetlić kilka grup problemów, które wydają się istotne dla syndromu amoralnego familizmu. Są to:

a) warunki sprzyjające ostremu podziałowi rzeczywistości społecznej na sferę prywatną i sferę publiczną,

b) czynniki prowadzące do dominacji w życiu społecznym roli rodziny, sieci przyjaciół, więzi nieformalnych, a więc do charakterystycznego zawężenia przestrzeni społecznej,

c) zjawiska sprzyjające zawężeniu czasu społecznego do ram teraźniejszości,

${ }^{47}$ Jacek Kurczewski, Drogi rekontrkultury, „Res Publica” 1988, nr 5, s. $22-23$. 
d) związane $z$ tym postawy i zachowania dezintegrujące, konkurencyjne, agresywne oraz stosowanie dwoistej etyki: innej dla „swoich”, innej dla „obcych".

W naszej analizie staraliśmy się pokazać rolę czynników ekonomicznych, wyrażających się w permanentnych niedoborach, niedostatku i ubóstwie. Wraz z czynnikami politycznymi tworzą one sytuacje, których istotą jest nieprzewidywalność, związana z poczuciem braku kontroli i wpływu na otaczającą rzeczywistość. Już sama ta sytuacja, odznaczająca się niejasnością, niepewnością, tymczasowością, działa dezintegrująco, prowadząc do powstawania między ludźmi więzi krótkotrwałych, byle jakich, bez dbałości o ich konsekwencje, a więc o jakość.

Obok tego rodzaju czynników staraliśmy się uwzględnić rolę tradycji, wzorów kultury nie związanych bezpośrednio z panującym systemem gospodarczo-politycznym. Tam właśnie dostrzegliśmy zjawiska i procesy, które bądź to wzmacniają, bądź osłabiają wpływ czynników systemowych. W tym celu odwoływaliśmy się do interpretacji interesujących nas zjawisk w kategoriach tradycji chłopskiej, kultury ubóstwa czy etyki katolickiej. Zdajemy sobie sprawę z tego, iż nasza analiza ma charakter wstępny i dalece nie wyczerpuje całej złożoności omawianej problematyki.

\section{'AMORAL FAMILISM,' OR ON THE SOCIAL DISINTEGRATION OF POLAND IN THE 1980s \\ Summary}

In this article the authors reflect on human relations phenomena that were characteristic of Polish society in the second half of the 1980s. These phenomena were not new nor have they been observed solely in this society. They appear everywhere and are strengthened in times of scarcity. In Poland they were made more severe by the breakdown of the communist system and the crisis connected with the systemic transformation. This was characterized by a strong dualism involving: (1) the division of the social sphere into public and private; (2) the narrowing of the social sphere to the family, a network of friends, and informal ties-a division into 'own' and 'other'; (3) a concentration on the present and on immediacy, with a dislike and inability to plan, think, or act in categories of the future; and (4) disintegrational, competitive, aggressive attitudes and behaviors, with a climate of distrust and enmity in human relations, and the application of a dual ethic - one for one's 'own' people and another for 'others.' This amoral familism, which characterizes a society composed of a collection of extended small groups built around the family and enlarged by friends, neighbors, and colleagues, is opposed to the world of institutions and is conditioned by both history and culture. The authors consider it to be factor in social anomy.

\section{Key words / słowa kluczowe}

amoral familism / amoralny familizm; anomy / anomia; Polish society / społeczeństwo polskie; family / rodzina; values / wartości 